\title{
Audit Internal dan Efektivitas Pengendalian Intern Penjualan
}

\author{
Radhi Abdul Halim Rachmat ${ }^{1 *}$, Ivan Gumilar Sambas Putra ${ }^{2}$ dan Ii Halilah \\ ${ }^{1}$ Fakultas Ekonomi, Universitas Widyatama, Indonesia \\ ${ }^{2}$ Fakultas Bisnis dan Manajemen, Universitas Widyatama, Indonesia \\ ${ }^{3}$ Jurusan Administrasi Niaga, Politeknik Negeri Bandung, Indonesia
}

\begin{abstract}
:
Sales activity plays an important role and needs to be controlled because it affects to the revenue. Sales control requires sales analysis that reveal undesirable developments need to be corrected. Internal Auditors who are not directly involved in operational activities can, therefore, assess all activities. Internal Auditors also provides objective information regarding sales data that will be the basis for management decision making. The purpose of this study is to: determine whether the internal audit on sales activities conducted by the company has been done adequately; determine whether the internal control over sales has been implemented effectively; and determine the role of internal audit in supporting the effectiveness of internal control sales. The authors perform hypothesis testing by doing descriptive analysis and statistical analysis. Based on the results, the effectiveness of internal control can be explained by the Internal Audit role of $63.2 \%$.
\end{abstract}

Keywords: internal audit, control, sales

\begin{abstract}
Abstrak:
Aktivitas penjualan memegang peranan penting dan perlu dikendalikan karena dari aktivitas inilah akan terbentuk pendapatan. Pengendalian penjualan memerlukan analisis aktivitas penjualan yang mengungkapkan perkembangan yang tidak diinginkan dan harus dikoreksi. Kedudukan Auditor Internal yang tidak terlibat langsung dalam aktivitas operasional memungkinkan mereka menilai semua aktivitas perusahaan. Audit Internal juga memberikan informasi yang objektif menyangkut keakuratan data penjualan yang akan dijadikan dasar pengambilan keputusan manajemen. Tujuan dari penelitian ini adalah untuk mengetahui apakah: pelaksanaan audit internal yang dilakukan perusahaan atas aktifitas penjualan telah terlaksana secara memadai; pengendalian intern atas penjualan telah dilaksanakan secara efektif; dan untuk mengetahui peranan audit internal dalam menunjang efektivitas pengendalian intern penjualan. Pengujian hipotesis dilakukan dengan analisis deskriptif dan analisis statistik. Berdasarkan hasil penelitian dapat diketahui bahwa efektivitas pengendalian internal bisa dijelaskan oleh peran Audit Internal sebesar 63,2\%.
\end{abstract}

Kata Kunci: audit internal, pengendalian, penjualan

\section{PENDAHULUAN}

Perkembangan dunia usaha yang semakin pesat, akan mengakibatkan persaingan yang semakin meningkat. Dalam

*Email korespondensi:

Radhi Abdul Halim Rachmat

radhiabdulhalimr@gmail.com usaha memenangkan persaingan perusahaan tidak terlepas dari adanya pengaruh intern dan ekstern, salah satu faktor internal yang penting adalah pengendalian dan pengawasan terhadap kegiatan perusahaan. Agar tercapai pelaksanaan pengawasan yang efektif. arah tujuan usaha awal perusahaan. Tujuan utama dari 
pembentukan perusahaan adalah untuk mencapai laba yang maksimal. Untuk mencapai tujuan tersebut perusahaan harus memanfaatkan dan mengelola bagian-bagian yang terdapat di dalam perusahaan secara efektif dan efisien. Untuk menjaga dan memelihara keefektifan pengendalian, maka perusahaan biasanya memerlukan suatu bagian khusus yang disebut bagian audit internal. Bagian audit internal dalam pelaksanaannya memerlukan sumber daya manusia yang telah dipilih secara objektif dan mempunyai kualifikasi sesuai dengan bidangnya, terampil, cakap dan yang lebih penting lagi memiliki integritas dan kejujuran. Bagian ini bertugas mengawasi dan mengevaluasi keefektifan setiap aktivitas pengendalian yang ada dalam perusahaan dan menjaga agar seluruh prosedur dan ketentuan yang berlaku di perusahaan dilaksanakan sebagaimana mestinya.

Tujuan audit internal menurut Tugiman $(1997 ; 11)$ adalah membantu semua anggota manajemen dalam melaksanakan tanggung jawab mereka dengan cara menyajikan analisis, penilaian, rekomendasi, dan komentar-komentar penting mengenai kegiatan mereka. Audit internal berhubungan dengan semua tahap kegiatan perusahaan, sehingga tidak hanya terbatas pada pemeriksaan terhadap catatan-catatan akuntansinya saja, tetapi juga harus memahami permasalahan-permasalahan dan kebijakan manajemen. Sedangkan menurut Boynton et al (2001;980) Pada dasarnya tujuan audit internal adalah membantu anggota organisasi lainnya dalam menjalankan tugas dan tanggung jawab secara efektif melalui analisis, penilaian, rekomendasi, konsultasi, dan peninjauan ulang atas informasi-informasi yang saling berhubungan. Oleh karena itu, auditor internal harus memperhatikan semua tahapan dari setiap kegiatan operasi perusahaan dan catatan akuntansi atas kecurangan serta hal lainnya

Pihak manajemen sebagai pihak pengambil keputusan memerlukan bantuan auditor internal dalam menentukan kebijakan yang tepat sesuai dengan kondisi yang ada dalam perusahaan berdasarkan analisis, penilaian serta saran-saran yang objektif serta independen agar tujuan perusahaan dapat tercapai.

$$
\text { Berdasarkan latar belakang }
$$
penelitian, maka penulis mendapati beberapa pokok masalah, antara lain:

1. Apakah audit internal telah dilaksanakan secara memadai.

2. Apakah pengendalian intern penjualan pada perusahaan telah dilaksanakan dengan efektif.

3. Bagaimana peranan audit intenal dalam menunjang efektivitas pengendalian intern penjualan.

\section{TINJAUAN PUSTAKA Audit Internal}

Audit internal merupakan suatu fungsi penilaian yang independen atas aktivitas-aktivitas yang dilaksanakan dalam suatu organisasi. Menurut Tugiman $(1997 ; 11)$ definisi audit internal adalah suatu fungsi penilaian yang independen dalam suatu organisasi untuk menguji dan mengevaluasi kegiatan organisasi yang dilaksanakan. Sedangkan menurut The Institute of Internal Auditors yang dikutip oleh Boynton et al $(2001 ; 980)$ definisi audit internal adalah Audit internal merupakan kegiatan yang dilakukan untuk menjamin pencapaian tujuan suatu organisasi. Kegiatan ini dirancang untuk memberikan suatu nilai tambah dalam rangka meningkatkan kualitas dari aktivitas operasional organisasi tersebut.

Program audit menurut Standar for Profesional Practice Internal Auditing tahun 2000 yang dikutip oleh Boynton et al (2001;983) adalah sebagai berikut:

1. Planning the audit, auditor internal harus merencanakan setiap pelaksanaan audit.

2. Examining and evaluating information, auditor internal harus mengumpulkan, menganalisa, menafsirkan, dan mendokumentasikan 
informasi untuk mendukung hasil audit.

3. Communicating result, auditor internal harus melaporkan hasil pekerjaan audit mereka.

4. Following up, auditor internal harus melakukan tindak lanjut untuk meyakinkan bahwa tindakan tepat telah diambil dalam melaporkan temuan audit.

Ruang lingkup audit internal meliputi pemeriksaan dan evaluasi ketepatan dan efektivitas struktur pengendalian intern organisasi dan kualitas atau mutu pelaksanaan kerja dalam memikul tanggung jawab yang dibebankan. Berikut ini ruang lingkup pekerjaan audit internal menurut Amin (2000)

1. Meneliti dan menilai baik tidaknya penerapan pengendalian akuntansi, keuangan, dan cara-cara pengendalian lainnya, serta meningkatkan pengendalian yang efektif dengan biaya yang wajar.

2. Meyakinkan sejauh mana kebijakan, rencana-rencana, prosedur-prosedur yang telah ditetapkan untuk ditaati.

3. Memeriksa sejauh mana kekayaan perusahaan dapat dipertanggungjawabkan dan diamankan terhadap segala macam kerugian atau kehilangan.

4. Memeriksa sejauh mana management data yang telah dikembangkan di dalam perusahaan dapat diandalkan.

5. Menilai mutu hasil pekerjaan dalam melaksanakan tanggung jawab atau kewajiban yang diserahkan.

6. Mengajukan rekomendasi atau saran untuk meningkatkan efisiensi operasi.

\section{Pengendalian Internal}

Menurut Sunarto $(2003 ; 137)$, yang dikutip dari COSO pengertian pengendalian intern adalah suatu proses yang dipengaruhi oleh dewan komisaris, manajemen, personel satuan usaha lainnya, yang dirancang untuk mendapatkan keyakinan memadai tentang pencapaian tujuan dalam hal-hal berikut : keandalan pelaporan keuangan, kesesuaian dengan undang-undang dan peraturan yang berlaku serta efektivitas dan efisiensi operasi. Dalam rangka merancang suatu pengendalian intern yang baik, perlu melihat tujuan pengendalian seperti yang dinyatakan oleh Sunarto $(2003 ; 138)$ yang dikutip dari Committee of Sponsoring Organization (COSO) adalah sebagai berikut : Reliability of financial reporting, Compliance with applicable laws and regulations and Effectiveness and efficiency of operations.

Komponen-komponen yang terdapat di dalam pengendalian intern menurut COSO yang dikutip menurut Sunarto $(2003 ; 142)$ adalah sebagai berikut:

1. Control environment (lingkungan pengendalian)

2. Risk assessment (penafsiran risiko)

3. Control activities (aktivitas pengendalian)

4. Information and communication (informasi dan komunikasi)

5. Monitoring (pemantauan)

Bagaimanapun baiknya pengendalian intern dalam suatu perusahaan, tidaklah menjamin sepenuhnya apa yang menjadi tujuan perusahaan dapat dicapai. Hal ini disebabkan karena pengendalian intern memiliki keterbatasan-keterbatasan yang dapat melemahkan pengendalian intern tersebut. Keterbatasan pengendalian intern seperti yang dikemukakan oleh Sunarto $(2003 ; 139)$ adalah sebagai berikut: kesalahan dalam pertimbangan, gangguan, kolusi, pengabaian oleh manajemen dan biaya lawan manfaat.

\section{Pengendalian Intern Penjualan}

Pengertian pengendalian intern penjualan menurut IAI $(2001 ; 319,2)$ adalah suatu proses yang dijalankan oleh dewan komisaris, manajemen, dan personel lain yang didesain untuk memberikan keyakinan yang memadai tentang pencapaian tiga golongan ini : a) keandalan informasi keuangan, b) efektivitas dan efisiensi operasi, dan c) kepatuhan terhadap hukum dan peraturan yang berlaku. Tujuan 
pengendalian intern penjualan adalah untuk mencapai tujuan perusahaan, baik mengenai produk atau jasa yang diberikan, penetapan harga atau tarif, metode penjualan, dan perencanaan.

\section{Audit Internal Penjualan}

Audit internal penjualan dikatakan efektif apabila memenuhi syarat-syarat sebagai berikut : adanya kualifikasi auditor internal, adanya program audit internal, adanya pelaksanaan audit internal, adanya laporan hasil audit internal dan adanya tindak lanjut dari laporan atau hasil-hasil audit internal. Jadi peranan audit internal dalam pengendalian intern penjualan meliputi audit terhadap semua aspek struktur pengendalian intern penjualan, sehingga dapat diketahui keefektifan struktur pengendalian intern penjualan.
Apabila terjadi ketidakefektifan pengendalian intern penjualan yang telah diperiksa, kemudian diberikan saran dan dilaporkan kepada manajemen. Selanjutnya manajemen melakukan tindak lanjut, kemudian tindak lanjut tersebut diperiksa sehingga berhasil, sehingga audit internal dapat berperan dalam meningkatkan pengendalian intern penjualan.

\section{METODOLOGI PENELITIAN}

Metode penelitian yang digunakan adalah verifikatif dimana dilakukan penyusunan deskripsi secara sistematis, pengungkapan fakta-fakta sifat-sifat hubungan antar variabel dan fenomena yang diteliti serta menginterpretasikan hubungan antar variabel tersebut berdasarkan data-data yang ada dengan pendekatan studi kasus.

Tabel 3 Variabel, Indikator, Sub Indikator, Skala Pengukuran, dan Instrumen

\begin{tabular}{|c|c|c|c|c|}
\hline Variabel & Indikator & Sub Indikator & $\begin{array}{c}\text { Skala } \\
\text { Pengukuran }\end{array}$ & Instrumen \\
\hline \multirow[t]{2}{*}{$\begin{array}{l}\text { Independen } \\
\text { Audit } \\
\text { Internal yang } \\
\text { Dilaksanakan } \\
\text { Secara } \\
\text { Memadai }\end{array}$} & $\begin{array}{l}\text { Berfungsinya } \\
\text { Audit Internal } \\
\text { atas Penjualan } \\
\text { yang Memadai }\end{array}$ & $\begin{array}{l}\text { 1. Kualifikasi Auditor Internal: } \\
\text { a. Independensi dan } \\
\text { objektivitas auditor } \\
\text { internal } \\
\text { b. Kompetensi auditor } \\
\text { internal }\end{array}$ & Ordinal & Kuesioner \\
\hline & & $\begin{array}{l}\text { 2. Pelaksanaan Audit Internal: } \\
\text { a. Ruang lingkup audit } \\
\text { internal } \\
\text { b. Program audit internal } \\
\text { c. Laporan audit internal } \\
\text { d. Tindak lanjut }\end{array}$ & Ordinal & Kuesioner \\
\hline \multirow[t]{2}{*}{$\begin{array}{l}\text { Dependen } \\
\text { Efektivitas } \\
\text { Pengendalian } \\
\text { Intern } \\
\text { Penjualan }\end{array}$} & $\begin{array}{l}\text { 1. Komponen } \\
\text { Pengendalian } \\
\text { Intern } \\
\text { Penjualan }\end{array}$ & $\begin{array}{l}\text { a. Lingkungan pengendalian } \\
\text { b. Perkiraan risiko yang akan } \\
\text { timbul } \\
\text { c. Aktivitas pengendalian } \\
\text { d. Informasi dan komunikasi } \\
\text { e. Pemantauan dan tindak lanjut }\end{array}$ & Ordinal & Kuesioner \\
\hline & $\begin{array}{l}\text { 2. Tercapainya } \\
\text { Tujuan } \\
\text { Pengendalian } \\
\text { Intern } \\
\text { Penjualan }\end{array}$ & $\begin{array}{ll}\text { a. Keabsahan } \\
\text { b. Kelengkapan } \\
\text { c. Penilaian } \\
\text { d. Klasifikasi } \\
\text { e. Tepat waktu } \\
\text { f. Posting dan pengikhtisaran }\end{array}$ & Ordinal & Kuesioner \\
\hline
\end{tabular}


Penelitian ini dilakukan pada satu perusahaan dengan cara mengambil beberapa unsur yang akan menjadi bahan penelitian untuk memperoleh data primer maupun data sekunder. Hal ini disebabkan karena setiap perusahaan walaupun perusahaan tersebut sejenis, pasti mempunyai masalah yang berbeda. Akan tetapi pada dasarnya setiap permasalahan yang terjadi membutuhkan perhatian yang sama. Dengan demikian hasil penelitian ini belum tentu berlaku bagi perusahaan yang mempunyai aktivitas yang sama dengan perusahaan yang menjadi objek penelitian ini. Adapun operasional variabel penelitian dapat dilihat pada Tabel 3.

\section{Objek Penelitian}

Yang menjadi objek penelitian dalam penelitian ini adalah penerapan audit internal dalam pengendalian penjualan pada PT Karya Utama Jayamegah yang berlokasi di Bandung, Jawa Barat.

Penelitian ini menggunakan sampel sebanyak 30 orang, yang terdiri dari Internal Auditor beserta para Staffnya, dan kepada Direktur, Branch Manager, Koordinator FAD Head, GM Sales \& Marketing, Sales Manager, GM Finance \& Administration, Chief Accounting, Finance Manager, HRD Manager beserta para staffnya.

\section{PEMBAHASAN}

\section{Analisis Pelaksanaan Audit Internal}

1. Ruang Lingkup Audit

Ruang lingkup audit yang dilakukan oleh auditor internal pada perusahaan telah memadai, yaitu auditor internal telah melaksanakan semua fungsi audit internal yang mencakup compliance, verification, dan evaluating.

2. Program Audit Internal

Program audit internal yang dilaksanakan pada perusahaan telah memadai. Program audit internal tersebut berisi hal-hal seperti objek pemeriksaan, waktu, dan tempat audit, tujuan audit, ruang lingkup audit, dan prosedur audit.

3. Laporan Hasil Audit

Laporan hasil audit dibuat setelah auditor internal selesai melaksanakan auditnya. Laporan tersebut memuat infomasi seperti tujuan audit, latar belakang audit, ruang lingkup audit, aktivitas yang dilakukan dalam mengaudit, temuan audit, rekomendasi, dan memuat informasi dan simpulan berdasarkan kenyataan yang ada, dan didukung oleh bukti-bukti yang cukup. Laporan tersebut harus dibuat ringkas, lengkap, wajar, dan akurat tanpa mengurangi kelengkapannya. Kemudian laporan tersebut diserahkan kepada Komisaris untuk mendapatkan tanggapannya mengenai saran dan rekomendasi yang telah diberikan. Penulis menyimpulkan bahwa laporan hasil audit yang dibuat oleh perusahaan telah memadai.

4. Tindak Lanjut Hasil Audit

Tindak lanjut hasil audit yang dilakukan oleh perusahaan bertujuan untuk memperbaiki atau menyempurnakan kebijakan dan priosedur yang masih memiliki kekurangan dan kelemahan, serta dalam pengendalian intern penjualan setelah mendapat tanggapan dari Komisaris sesuai dengan laporan hasil audit yang telah diserahkan oleh auditor internal. Tindak lanjut diberi batas waktu sehingga dapat dipastikan bahwa tindak lanjut tersebut telah dilakukan oleh bagian yang terkait. Dengan demikian auditor internal mendapat dukungan manajemen, sehingga auditor internal dapat meminta tanggapan atas temuan-temuan audit dan penilaian koreksi yang harus dilaksanakan. Jadi penulis menyimpulkan bahwa tindak lanjut hasil audit pada perusahaan telah memadai. 


\section{Analisis Komponen Pengendalian Intern Penjualan}

Pengendalian intern yang memadai dapat membantu manajemen dalam meningkatkan keandalan pelaporan, meningkatkan efektivitas dan efisiensi operasi perusahaan, dan meningkatkan ketaatan terhadap kebijakan dan prosedur yang telah ditetapkan. Berdasarkan hasil penelitian yang penulis lakukan, pengendalian intern penjualan yang dilaksanakan pada perusahaan telah memadai, ini dapat dilihat melalui:

1. Lingkungan Pengendalian yang Memadai

a. Adanya integritas dan nilai-nilai etika dalam perusahaan yang dilaksanakan oleh karyawan secara etis dalam pekerjaannya yang terlihat dalam peraturan perusahaan, tata tertib, dan adanya sangsi yang tegas sehingga karyawan memiliki kedisiplinan, ketelitian, dan kejujuran dalam pekerjaan maupun membuat laporan.

b. Adanya sistem perekrutan karyawan dengan adanya test bagi calon karyawan yang ketat, karyawan diberikan penjelasan mengenai tugas dan tanggung jawab masing-masing, dan juga perusahaan mengadakan pelatihan (training) dan pengembangan kemampuan karyawan.

c. Perusahaan tidak memiliki Komite Audit, tetapi hal ini tidak mempengaruhi pelaksanaan audit perusahaan yang cukup memadai. Perusahaan mempunyai auditor internal yang independen sehingga dapat melaksanakan audit secara keseluruhan dengan baik.

d. Dalam mencapai tujuan usahanya, perusahaan menekankan bahwa pentingnya kepuasan konsumen, dengan pengendalian yang baik dan karyawan yang cakap dalam mendukung kelangsungan hidup perusahaan. e. Struktur organisasi yang menunjukan adanya pemisahan tugas yang baik serta pembagian tugas dan wewenang yang memadai yang memperlihatkan secara jelas kepada siapa bawahan bertanggung jawab.

f. Adanya pemisahan wewenang dan tanggung jawab yang dilaksanakan dengan baik.

2. Penafsiran Risiko yang Memadai Yaitu adanya sistem pencatatan yang memadai dalam penilaian risiko yang berhubungan dengan penyajian laporan keuangan yang sesuai dengan Standar Akuntansi Keuangan (SAK), adanya kebijakan dan prosedur yang memadai untuk penilaian risiko yang berhubungan dengan pengendalian intern guna mengurangi kemungkinan kesalahan dan ketidakberesan yang material pada perusahaan.

3. Aktivitas Pengendalian yang Memadai

a. Adanya tinjauan pelaksanaan kerja yang memadai, yaitu mengadakan perbandingan hasil kerja yang sesungguhnya dengan anggaran, peramalan, dan periode kerja sebelumnya, serta analisis dan tindakan koreksi yang dilakukan.

b. Adanya pengolahan informasi yang memadai, ini terlihat dengan adanya pengendalian terhadap keabsahan transaksi, otorisasi transaksi yang dilakukan oleh pejabat yang berwenang, dokumen yang prenumbered sehingga informasi yang diperoleh akurat.

c. Adanya pengendalian fisik terhadap aktiva dan catatan penjualan yang cukup memadai, sehingga dapat mengurangi adanya kecurangan atau penyelewengan.

d. Adanya pemisahan tugas yang memadai, terlihat pada struktur organisasi perusahaan.

4. Informasi dan Komunikasi yang Memadai

Yaitu adanya informasi yang akurat dan komunikasi yang baik dalam menunjang 
terciptanya pengendalian penjualan, sehingga informasi dan komunikasi ini dapat mempengaruhi manajemen dalam membuat keputusan mengenai pengelolaan dan pengendalian perusahaan.

5. Pemantauan yang Memadai

Yaitu adanya aktivitas pengawasan atau pemantauan yang dilakukan manajemen secara berkesinambungan terhadap kebijakan dan prosedur perusahaan sehingga melalui pengawasan ini dapat diketahui kekurangan dari sistem pengendalian yang ada pada perusahaan. Hal tersebut dipandang perlu agar manajemen dapat menganalisa sampai sejauh mana perencanaan yang telah disusun perusahaan telah dilaksanakan dan manajemen juga dapat terus mengadakan perbaikan apabila dalam penyelesaian masalah tersebut masih terdapat kekurangan.

\section{Analisis Tujuan Pengendalian Intern Penjualan}

Tujuan pengendalian intern penjualan PT Karya Utama Jayamegah adalah sebagai berikut :

1. Tidak ada penjualan yang fiktif.

2. Penjualan yang terjadi telah dicatat seluruhnya.

3. Penjualan yang dicatat adalah barang yang dikirim dan ditagih, serta yang dicatat dengan benar.

4. Transaksi penjualan telah diklasifikasikan dengan benar.

5. Seluruh penjualan telah dicatat pada tanggal yang benar.

6. Transaksi penjualan telah dimasukkan dengan benar dalam buku tambahan dan telah diikhtisarkan dengan benar.

Untuk dapat terlaksananya tujuan pengendalian intern penjualan tersebut, perusahaan telah mematuhi hukum dan peraturan yang telah ditetapkan, antara lain:

1. Ketaatan terhadap kebijakan dan prosedur order penjualan, yang dapat dilihat sebagai berikut : a. Pesanan penjualan dari konsumen diterima oleh bagian penjualan dan dicatat oleh bagian administrasi penjualan dalam buku pesanan penjualan.

b. Sebelum aktivitas penjualan pada perusahaan dilakukan, manajer pemasaran terlebih dahulu menentukan waktu pengiriman, harga, komisi, dan jenis pembayaran yang sesuai dengan desain dan jenis dari produk yang bersangkutan.

c. Pembayaran hanya dapat dilakukan melalui Letter of Credit (L/C), Down Payment (D/P), atau Telex Transfer (T/T).

2. Kebijakan dan prosedur retur penjualan yang ditetapkan telah ditaati, hal ini dapat dilihat dari :

a. Retur penjualan terjadi jika barang yang diterima oleh konsumen mengalami kerusakan atau cacat, salah dalam jumlah pengiriman yang dipesannya.

b. Retur penjualan tersebut harus diotorisasi terlebih dahulu oleh bagian penjualan.

c. Retur penjualan hanya boleh tiga bulan sejak tanggal terjadinya transaksi penjualan.

3. Ketaatan terhadap peraturan-peraturan dan perundang-undangan yang berlaku, yaitu :

a. Gaji dan upah yang diberikan perusahaan telah sesuai dengan standar gaji yang ditetapkan (UMR).

b. Perusahaan memberlakukan jam kerja sesuai dengan peraturan yang telah ditetapkan pemerintah.

Pengendalian intern penjualan memiliki keterbatasan-keterbatasan yang dapat menghambat tercapainya tujuan perusahaan. Keterbatasan-keterbatasan tersebut antara lain:

1. Terjadinya persekongkolan diantara karyawan yang menangani penjualan dalam usaha untuk menggelapkan harta perusahaan. 
2. Adanya kelemahan manusia seperti kelelahan fisik yang mengakibatkan menurunnya tingkat ketelitian dalam bekerja.

Karena keterbatasan-keterbatasan tersebut, diperlukan audit internal agar apabila terjadi kesalahan atau penyelewengan dapat segera diatasi. Dengan adanya auditor internal dapat dilakukan audit dan melaporkan kelemahan atau kecurangan yang terjadi, sehingga manajemen dapat mengambil tindakan yang cepat dan tepat untuk mengantisipasinya agar kerugian yang timbul dapat ditekan serendah mungkin, oleh karena itu peranan audit internal sangat diperlukan oleh manajemen.

\section{Analisis Peranan Auditor Internal dalam Menunjang Efektivitas Pengendalian Intern Penjualan}

Berdasarkan hasil dari keseluruhan pembahasan yang telah dikemukakan oleh penulis pada bagian-bagian sebelumnya, maka penulis dapat menjelaskan secara keseluruhan penelitian baik dari pengamatan, wawancara, dan hasil dari kuesioner tentang peranan audit internal dalam menunjang efektivitas pengendalian intern adalah sebagai berikut :

1. Kedudukan auditor internal dinilai independen dan objektif, karena tidak terlibat langsung dalam aktivitas operasional yang rutin sehingga dapat melaksanakan tugasnya dengan baik dan bertanggung jawab langsung kepada Komisaris.

2. Auditor internal yang ada memiliki pengetahuan dan kemampuan teknis yang memadai dalam melaksanakan audit dan juga memiliki ketegasan sikap, teliti, dan bertanggung jawab atas hasil audit yang dilakukan.

3. Ruang lingkup audit yang dilaksanakan telah mencakup Compliance, Verification, dan Evaluating terhadap kebijakan dan prosedur yang ada di perusahaan.
4. Adanya program audit yang merupakan pedoman bagi auditor internal dalam melaksanakan audit agar audit yang dilakukan tersusun dan terencana dengan baik.

5. Laporan audit dibuat setelah audit dilakukan, laporan tersebut berisi temuan-temuan hasil audit, rekomendasi, dan saran mengenai kelemahankelemahan yang ditemukan dengan melampirkan bukti-bukti temuan yang diperoleh.

6. Adanya tindak lanjut atas objek yang diperiksa dan kemudian dilakukan pemantauan terhadap tindak lanjut perbaikan yang dilaksanakan.

Khususnya untuk audit internal penjualan, kegiatan audit internal dapat dikemukakan secara singkat sebagai berikut:

1. Audit dilakukan terhadap sistem dan prosedur penjualan yang mencakup prosedur penjualan, pengiriman barang kepada konsumen, dan pengeluaran barang dari gudang.

2. Audit dilakukan untuk memberikan keyakinan bahwa catatan dan pelaksanaan penjualan adalah benar.

Pada akhirnya penulis dapat menyimpulkan bahwa efektivitas pengendalian intern pada PT Karya Utama Jayamegah dalam menunjang efektivitas penjualan telah dipenuhi secara baik walaupun terdapat penyimpanganpenyimpangan dari segi data volume penjualan yang ada dikarenakan faktorfaktor eksternal yang tidak dapat dikendalikan.

\section{Pengujian Hipotesis}

Guna mendukung pengujian hipotesis, penulis melakukan penelitian dengan menyebarkan kuesioner yang berisi pertanyaan sehubungan dengan masalah yang penulis bahas kepada 30 orang responden yang di PT Karya Utama Jayamegah. Pertanyaan yang diajukan penulis berjumlah 29 buah pertanyaan untuk variabel independen, yaitu pertanyaan mengenai peranan audit internal yang 
memadai, serta 33 buah pertanyaan untuk variabel dependen, yaitu pertanyaan mengenai efektivitas pengendalian intern penjualan.

\section{Pengaruh Peran Audit Internal Terhadap Efektivitas Pengendalian Internal}

Peran audit internal terhadap efektivitas pengendalian internal dapat dijelaskan pada Tabel 2.

Tabel 2 Peran Audit Internal Terhadap Efektivitas Pengendalian Internal

\begin{tabular}{|ll|r|r|}
\hline & $\begin{array}{c}\text { Peran Audit } \\
\text { Internal }\end{array}$ & $\begin{array}{c}\text { Gaya } \\
\text { Kepemim } \\
\text { pinan }\end{array}$ \\
\hline Pearson Correlation & Peran Audit Internal & 1.000 & .795 \\
& Efektivitas P Internal & .795 & 1.000 \\
\hline Sig. (1-tailed) & Peran Audit Internal &. & .000 \\
& Efektifvitas P internal & .000 &. \\
\hline N & Peran Audit Internal & 240 & 240 \\
& Efektivitas P Internal & 240 & 240 \\
\hline
\end{tabular}

Dari Tabel 2 dapat disimpulkan bahwa hubungan antara peran audit internal terhadap efektivitas pengendalian internal di dapat angka sebesar 0.795 ini berarti variabel peran audit internal mempunya pengaruh yang kuat terhadap variabel efektivitas pengendalian internal dikarenakan nilai korelasi $>0.5$, dan tanda (+) positif mempunyai arti hubungan yang searah dimana jika peran audit internal meningkat maka akan mempengaruhi peningkatan terhadap variabel efektivitas pengendalian internal.

Data Tabel 3 dianalisis sebagai berikut:

1. Angka $\mathrm{R}$ sebesar 0,632 menunjukan bahwa korelasi antara Peran Audit internal dengan Efektivitas Pengendalian Internal adalah cukup

2. Angka $\mathrm{R}$ square atau koefisien determinasi sebesar 0,632 berasal dari $\left(\mathrm{R}^{2}=0.795^{2}\right)$. Hal ini berarti $63,2 \%$ Efektivitas Pengendalian Internal bisa dijelaskan atau dipengaruhi oleh Peran Audit internal. sedangkan sisanya 36,8\% $(100 \%-63.2 \%)$ disebabkan oleh faktorfaktor lain.
Tabel 3 Pengaruh Peran Audit Internal Terhadap Efektivitas Pengendalian Internal

\begin{tabular}{|c|r|r|r|}
\hline $\mathrm{R}$ & $\begin{array}{c}\mathrm{R} \\
\text { Square }\end{array}$ & $\begin{array}{c}\text { Adjusted R } \\
\text { Square }\end{array}$ & $\begin{array}{c}\text { Std. Error of } \\
\text { the Estimate }\end{array}$ \\
\hline .795 & .632 & .630 & .38749 \\
\hline
\end{tabular}

Hipotesis Simultan

$\mathrm{H}_{0}: \beta_{\mathrm{yx}}=0$, Tidak terdapat pengaruh Peran Audit internal (X), terhadap Efektivitas Pengendalian Internal (Y) pada PT Karya Utama Jayamegah

$\mathrm{H}_{\mathrm{a}}: \beta_{\mathrm{yx}} \neq 0$, Terdapat pengaruh Peran Audit internal (X), terhadap Efektivitas Pengendalian Internal (Y) pada PT Karya Utama Jayamegah

Berdasarkan hasil perhitungan regresi linier dan koefisien determinasi, dapat dihitung statistik uji untuk setiap koefisien sebagaimana tergambarkan pada Tabel 4.

Tabel 4 Regresi Linier

\begin{tabular}{|ll|c|c|c|c|c|}
\hline Model & & $\begin{array}{c}\text { Sum of } \\
\text { Squares }\end{array}$ & df & Mean Square & F & Sig. \\
\hline 1 & Regressior & 71.084 & 1 & 35.542 & 323.813 & $.000^{8}$ \\
& Residua & 26.013 & 29 & .11 & & \\
& Total & 97.098 & 30 & & & \\
\hline
\end{tabular}

Berdasarkan perhitungan di Tabel 4, maka dapat disimpulkan bahwa audit internal pada Berdasarkan hasil pengolahan data pada output anova diperoleh signifikansi sebesar 0,000 sedangkan alpha $(\alpha)$ yang dipakai dalam penelitian ini adalah sebesar 0,05, maka signifikansi lebih besar dari alpha $(\alpha)$. Hal ini berarti $H_{o}$ ditolak dan $H_{a}$ yang artinya Terdapat pengaruh Peran Audit internal (X), terhadap Efektivitas Pengendalian Internal (Y) pada PT Karya Utama Jayamegah.

\section{KESIMPULAN}

Kesimpulan

Berdasarkan hasil penelitian dan pembahasan yang dilakukan penulis serta didukung dengan data yang diperoleh 
selama penelitian, penulis menarik simpulan sebagai berikut:

1. Audit internal penjualan yang dilaksanakan pada PT Karya Utama Jayamegah telah memadai, hal ini dapat diketahui dari:

a. Kualifikasi auditor internal yang memadai, yaitu: kedudukan auditor internal yang independen dan cukup kompeten.

b. Pelaksanaan audit internal yang memadai, yaitu: adanya ruang lingkup audit, program audit, laporan audit, dan tindak lanjut audit.

2. Pengendalian internal penjualan sangat efektif, dapat diketahui dengan:

a. Dipenuhinya komponen-komponen pengendalian intern sebagai berikut:

1) Lingkungan pengendalian yang efektif

2) Penetapan risiko yang efektif

3) Aktivitas pengendalian yang efektif

4) Informasi dan komunikasi yang efektif

5) Pemantauan atau pengawasan yang dilakukan oleh auditor internal dan manajemen secara berkesinambungan.

b. Dipenuhinya tujuan pengendalian intern penjualan sebagai berikut:

1) Tidak ada penjualan yang fiktif.

2) Penjualan yang terjadi telah dicatat seluruhnya.

3) Penjualan yang dicatat adalah barang yang dikirim dan ditagih, serta yang dicatat dengan benar.

4) Transaksi penjualan telah diklasifikasikan dengan benar.

5) Seluruh penjualan telah dicatat pada tanggal yang benar.

6) Transaksi penjualan telah dimasukkan dengan benar dalam buku tambahan dan telah diikhtisarkan dengan benar.

3. Audit internal penjualan yang dilaksanakan oleh PT Karya Utama Jayamegah sangat berperan dalam menunjang efektivitas pengendalian intern penjualan, hal ini dapat diketahui dari:
a. Audit internal mengevaluasi pelaksanaan prosedur-prosedur yang berhubungan dengan penjualan.
b. Auditor internal mengecek ketelitian pelaksanaan aktivitas penjualan.
c. Auditor internal memeriksa ada tidaknya persekongkolan yang terjadi antar bagian yang terlibat dalam aktivitas penjualan.
d. Auditor internal memeriksa penerapan metode pencatatan dan pelaporan penjualan.
e. Auditor internal meneliti kelengkapan dan kebenaran catatan penjualan.

\section{Saran}

Adapun saran yang penulis kemukakan adalah sebagai berikut:

1. Sebaiknya audit internal dilakukan secara rutin, misalnya enam bulan sekali. Sehingga apabila terdapat masalah yang cukup besar akan lebih cepat diketahui dan pemecahan masalahnya akan lebih cepat diambil serta tidak berlarut-larut sehingga tidak akan menimbulkan kerugian terhadap perusahaan.

2. Sebaiknya auditor internal lebih sering lagi diikutsertakan dalam seminarseminar tentang audit internal sehingga dapat mengikuti perkembangan yang berhubungan dengan audit internal yang ada agar dikemudian hari tidak menjadi kendala dalam pelaksanaan pengendalian intern di perusahaan.

\section{DAFTAR PUSTAKA}

Ajzen, I. (1991). The Theory of Planned Behavior. Organizational Behavior and Human Decision Process, Vol. 50, 179211.

Amana, N.I. (2002). Analisis Profil Demografis Dan Psikografids Perokok Merek Marlboro. Tugas Akhir Sarjana Jurusan Teknik Industri, Institut Teknologi Bandung. 
Cohen, J., \& Cohen. P. (1983). Applied Multiple Regression / Correlation Analysis for the behavioral Sciences, $\left(2^{\text {nd }} e d\right)$. London: Lawrence Erlbaum Associates Publisher.

Dajan, A. (1986). Pengantar Metode Statistik, Jilid II. Jakarta: LP3ES.

Fishbein. M., \& Ajzen. I. (1975). Belief, Attitude, Intention and Behavior : An Introduction to Theory and Research. Manila: Addisson-Wesley Company Inc.

Fishbein. M., \& Ajzen. I. (1980), Understanding Attitude and Predicting Social Behavior. London: Prentice-Hall International, Inc.

Hays, W.L. (1969). Quantification in Psychology : A life Span Approach. New Delhi: Prentice Hall of India Private Limited.

Utamadi, G. (2002). Rokok Bagi Remaja, Gaya atau Bahaya?. Jakarta: Kompas.

Koncara, A. (2009). Analisis Pengaruh Sikap dan Norma Subjektif Terhadap Intensi serta Perilaku Mengkonsumsi Produk $X$ di Kalangan Remaja Berdasarkan TRA.Tesis Magister, Instutut Teknologi Bandung.

Kotler, P. (1980). Principles of Marketing. New Jersey: Prentice-Hall.

Mandel, M. J. (1974). The Background of Advertising and It's Social Impaction. New Jersey: Prentice-Hall.

Nurhayati, A. (2001). Pengukuran Minat Konsumen Untuk Membeili Berdasarkan Model Ajzen dan Fishbein (studi kasus : Produk Minyak Goreng). Tugas Akhir Sarjana jurusan Teknik Industri. Institut Teknologi Bandung.

Peslak, A., Ceccucci, W., \& Sendall, P. (2011). An Empirical Study of Socialing Networking Behaviour Using Theory of Reasoned Action. CONISAR Proceedings Vol. 4 No. 1807. 